\title{
THE ROLE OF THE COMMUNITY AROUND THE BUFFER VILLAGE IN THE CONSERVATION OF ALAS PURWO NATIONAL PARK BASED ON LOCAL WISDOM
}

\author{
Eko Setiawan ${ }^{*}$, Keppi Sukesi², Kliwon Hidayat ${ }^{2}$, Yayuk Yuliati² \\ ${ }^{1}$ Postgraduate Students of Sociology, Faculty of Agriculture, Brawijaya University. ${ }^{2}$ Professor of Rural Sociology, Faculty of \\ Agriculture, Brawijaya University, Indonesia *Corresponding Author’s Email: eko.pacerot@gmail.com
}

\begin{abstract}
This study describes the lives of people in the buffer area of Alaspurvo National Park, especially Kutorejo Village Kalipait Hamlet, which has local wisdom in the form of many traditions, rules, and abstinences that are still passed down through generations. This local wisdom has the value of ecological intelligence about the relationship of human activity with its ecosystem. Local wisdom owned by the community is used as a reference in the management of forest areas and coastal waters, both in the form of myths and abstinence. The center of attention of ecological studies according to Julian Steward is the process of cultural adaptation to the environment. This process is seen as a form of dialectic relationship in the context of interdependence with others. The type of research used in case study design is descriptive and qualitative. The results showed that the community around Alas Purwo National Park has local wisdom in the form of a number of traditions, rules or restrictions that are still valid for generations which are then maintained and obeyed until now. The abstinence is in the form of a ban on killing peacocks and abstinence in the payang system.
\end{abstract}

Keywords: Conservation, Alas Purwo National Park, Local Wisdom.

\section{INTRODUCTION}

Indonesia is still ranked second in the world in terms of biodiversity wealth, after Brazil. Indonesia has 300,000 species of animals or $17 \%$ of the world's animals (1). Indonesia's wealth of species includes 515 species of mammals, 1,539 species of birds, $45 \%$ of the number of fish species, $16 \%$ of reptile species, $15 \%$ of insect species in the world are also found in Indonesia (2). Indonesia's tropical forests are the second largest in the world after Brazil (3). Indonesia is one of the Megacenter of biodiversity countries (4). The abundance of plants and wildlife in Indonesia, placing Indonesia as the country with the third highest level of diversity in the world (5). The Government of Indonesia has established a conservation area of 521 units, with an area of 27.1 million hectares to protect biodiversity wealth (6). One of them, forest is a natural wealth that must be maintained as a counterbalance to nature and the lungs of the earth. Forest ecosystems have a variety of biodiversity and non-biodiversity. Forests are a very potential area in the socioeconomic life of people living around the forest. People living around forests or so-called traditional communities are inseparable because they are part of a forest ecosystem.

Kalipait village is the clearest portrait of how unique the adaptability of the social structure of society is. The lives of its people are on magersari land, and have a key position in forest management. While Kutorejo Village is a hamlet that is directly adjacent to the alas purwo national park area, so the activities of various activities

CThe Author(s) 2021. Published by Iquz Galaxy Publisher, India.. This is an Open Access article distributed under the terms of the Creative Commons Attribution CC BY license (http://creativecommons.org/licenses/by/4.0/), which permits unrestricted reuse, distribution, and reproduction in any medium, provided the original work is properly cited.

(Received 14 April 2021; Revised 19 May 2021; Accepted 22 June 2021) 
depend on the national park quite high. Every day they have to go in and out of the forest, to look for forest products and marine biota. Forests are not only a source of daily necessities, but also have social, cultural and religious functions. Forests and communities around the national park area there is a very close bond that has been going on since hundreds of years ago. The community around the national park has local wisdom values formed from repeated interactions between the community and the forest. As a result, a system of socio-cultural order of the community was developed that blended with the forest ecosystem.

Various activities of people in the forest area at that time continued to approach the core zone, where they used to set up temporary settlements as a resting place to search for forest products and marine biota. Actually, challenges in forest protection and management in Indonesia often come from people living around forests. Magdalena (2013) stated that the sustainability of forest management is highly dependent on the participation of local communities in management (7). The relationship between forests and local communities is inseparable from the concept of ecosystems, an ecological system formed by the reciprocal relationship between living things and their environment (8).. Gauthama, et al (9) mentioned that Javanese people implement the nature of human relationship with nature with philosophy memayu hayuning bawana (trying to keep the world and all its contents in order to remain maintained and harmonious).

Actually, the interaction of the community to the forest with local wisdom has been going on for a long time before the establishment of the area into a conservation area. Local wisdom that supports conservation is formed from the interaction between humans and their environment so that traditional people have a deeper understanding of the environment (10). Local wisdom shows an inseparable relationship between human behavior and its environment. Mastery of local wisdom will carry their virtuous soul (11). Similar to liliweri (2014), that local wisdom can be interpreted as a view of life that develops in a certain social and ethnic community that is limited by regional elements, geographical location, and unique historical experience (12).

Efforts to study the interconnectedness of community interactions have actually been conducted, but still have not provided comprehensive results. Van Assendelf (1991) has conducted research on the human impact on the Alas Purwo National Park area, but this study only describes various human activities along the coastline, not specifically identifying the influence of human activity (13). More complex research on human interplay with country wide park regions have absolutely been performed with the aid of using Pramusanti (2001) however most effective confined to interacting with the network withinside the series of herbal resources (14). Febriyanti (2007) in her research aims to know the condition of mangrove forests and their contribution to the household income of the community from economic value to the community around alas purwo national park area (15). Satyasari (2010) mangrove ecotourism activities in Alas Purwo National Park provide economic benefits for the local community, therefore the development of mangrove ecotourism in Bedul tends to meet the principle of profit for the local community (16). Azmi (2015) in his research, assessed the use and value of species for kalipahit villagers around Alas Purwo National Park (17). Species have a symbolic role and value for the stability of cultural groups over time defined as key species of culture. Fiddarain (2016) research studies only in the Patuk block area, as a problem solving strategy that is integrative solutions in order to realize a joint agreement to increase concern for the preservation of alas purwo national park area (18). Some cases of failure in conservation above as conveyed by Iswandono (2016) in this study there is no meeting point in the joint management between forest area managers and traditional communities in conducting forest conservation, therefore forest management should integrate local wisdom with conservation principles (19). Local know-how that helps biodiversity conservation has the identical goal, particularly the belief of biodiversity sustainability for the welfare of the community, however conventional understanding is poorly understood due to the fact it's far taken into consideration historic and unreasonable (20).

The urgency of the assessment of participation in participation activities in conservation activities that are top down is proven to give no maximum results. Mendez-Lopez (2014) conducted research in Mexico also acknowledged 
that the low participation of the community in conservation activities due to the many conditions of the community is still passive (21). Similar findings Thaman (2016) proves the participation of rural communities in conservation activities in Portugal only 43\%, making conservation ineffective (22). In Fiji, the buttom up approach shows $88 \%$ greater community engagement, making conservation activities effective. The effect of community participation on conservation success can also be seen in Costa Rica, when the community participates then the private sector is involved (23). This condition gives the meaning of activities that use participatory approach and togetherness will give good results.

From the description above, it appears that with the heterogeneity of existing society, it causes a variation of socio-cultural behavior in the community towards the environment. With the uniqueness, cultural diversity, environmental relations and traditional communities in the Alas Purwo National Park area, making the uniqueness and attractiveness to be researched in accordance with the problems of this modern age. As has been done by previous researchers who are still in touch with humans and their environment. Novelty research is to find a way to conserve biodiversity by integrating the local wisdom of the community around the Alas Purwo National Park area. The importance of understanding local wisdom has been expressed by Ihsannudin (2015b) that local wisdom in the conservation of natural resources owned, as it is in the masalembu community was able to foster community participation in the conservation of natural resources (24). It cannot be forgotten that social capital must be optimized in the management of natural resources in order to be optimal (25). In response, Liberati (2016) proposed a partnership in the form of stakeholder participation (26).

There have been many studies that integrate local wisdom and conservation with different research focuses, including: focus on zoning (27), while the differences, methods and processes of national park integration (28), traditional ecological knowledge of species populations (29). Classification of vegetation and environment (30). This research is expected to provide benefits for stakeholders, as well as support for national park managers to engage traditional communities around buffer villages by integrating local wisdom into conservation activities.

\section{RESEARCH METHODOLOGY}

This research uses the paradigm of constructivism as a philosophical basis for understanding the reality of society. Using qualitative approach with case study design. Qualitative research emphasizes processes and meanings that are not rigorously tested or measured in terms of quantity (31). The data used is qualitative data that does not consist of numbers, but rather in the form of images and data (32). In addition qualitative research methods are defined as a process to gain a better understanding of complexity in human interaction (33). The nature of qualitative research is to observe people in their living environment and interact with them, trying to understand them about the surrounding world with the aim of understanding, exploring their views and experiences to get the necessary information (34). The purpose of descriptive research is to describe objects as they are (35). In order to obtain maximum results, strategies and research techniques are chosen that are considered appropriate and accountable. Informants are defined by purposive techniques. Data collection using observations and interviews. This research focuses on extracting data on local community interactions around the Alas Purwo National Park area and public perception and the social, economic, cultural factors behind it. Thus, the harmonization of communication and interaction can be achieved to the maximum (36). Data analysis using interactive models, including data collection components, data reduction, data serving, conclusion drawing.

\section{RESULTS AND DISCUSSION}

\section{THE EXISTENCE OF THE COMMUNITY AROUND THE BUFFER VILLAGE}

Kalipait village is a village in Banyuwangi Regency which is located in the southern tip area, precisely approximately $60 \mathrm{~km}$ from the Banyuwangi Regency Government Center to the South of the path to Alas Purwo National Park. Kalipait village is the clearest portrait of how unique the adaptability of the social structure of society is. The life of the people living in buffer villages has a key position in forest management. While Kutorejo 
Village is directly adjacent to the alas purwo national park area, so the various activities with the national park are very high. Every day they have to go in and out of the forest, to look for forest products and marine biota. The interaction between the community around the buffer village and Alas Purwo National Park is intense because the dependence of the community on natural resources is still high. The economic level of residents in buffer areas is still relatively low, and many depend on the utilization of natural resources. The form of community interaction around the buffer village with Alas Purwo National Park is the collection of forest products, beaches, which exist within the national park area, known as kayal.

Alas Purwo National Park area management in Banyuwangi regency is considered still less effective. This is because the management has not achieved the set goals. In addition, the extent of forest areas and the many problems of disturbance to the forest area itself. Law No. 5 of 1990 on Conservation of Biological Natural Resources and Their Ecosystems mandates the importance of biodiversity protection efforts, including wildlife in the region. It seems that the Law has not been implemented optimally, there are still many violations such as hunting protected animals, especially one wild animal that is threatened by the population because of poaching is the bull (Bos javanicus d'Alton), and the green cucak bird. The threat to the existence and population of bulls and green cucaks has been a long time coming. The situation and condition of the national park which is directly adjacent to the settlement, especially Kutorejo Hamlet makes it vulnerable to conflict. One of the triggers of the conflict is the presence of wildlife that exits the area and disturbs the land of the surrounding community (37).

In addition, problems in voting activities conducted by the community, in addition to providing economic value to the community, this activity also tends to result in damage to natural resources. There is still no recognition of community activities in the management of national parks, so there is no regulation or policy that accommodates this issue. So that in the end the victim is the natural resources of the national park itself. Whereas both the manager and the local community around the area both have the need for guaranteed sustainability of natural resources. National park managers have a category against any form of violation or disturbance. First, the category of high violation rate is all forms of activities that result in death or loss of resources, such as wildlife hunting, timber theft. Second, the category of moderate violation level includes bamboo and gebang voting activities. Third, the category of interference with low violation rates includes the collection of firewood. Large-scale collection of wood and bamboo can decrease the carrying capacity of the environment (38). One way to minimize disruption to natural resources is to involve the community in the management activities of national parks as partners. Because with the recognition of community voting activities, it means that the community feels firsthand the benefits of the existence of the national park, and at the same time has a responsibility to maintain the ecosystem.

The community around the national park has local wisdom formed from repeated interactions between the community and the forest. As a result, a system of socio-cultural order of the community was developed that blended with the forest ecosystem. Forests become a unified cultural environment to be the focus of people's lives around the national park area to support the system of life. The center for the study of the theory of cultural ecology of Julian $\mathrm{H}$ Steward is the environment and culture fused dialectic relationships. In other words, the ecological process has reciprocal laws and influences each other because culture and environment are not entities that each stand alone or are not static finished goods (39). In that case the concept of adaptation becomes the central concept between man and his culture and the physical natural environment in which man lives and develops.

The humans round Alas Purwo National Park place have nearby information withinside the shape of some of traditions, withinside the shape of policies or regulations which are nevertheless legitimate for generations and obeyed through the community. Local wisdom has the value of ecological intelligence that needs to be maintained and developed so as not to be tempted by modernization. Local wisdom owned by the community is used as a reference in the management of forest areas, in the form of myths 
and practices of religious rituals. They consider that the forest is a sacred gift from God. They think that the gift should be maintained so as not to be destroyed, or over-exploited. In addition, they also believe that the forest has magical powers, and supported the existence of myths passed down since the time of ancestors. The surrounding community through mythical concepts, ritual practices, management of forest areas, they strive to always maintain the relationship between the natural environment in order to remain harmonious. The local community in general is very well acquainted with the surrounding environment. They live in a variety of natural ecosystems, and have long coexisted with nature harmoniously so as to know various ways of utilizing natural resources sustainably. Local information owned via way of means of the villagers then has implications each for the surroundings and for the lives of the human beings across the countrywide park area. Forest management activities in the national park area, with the local wisdom has a positive impact on the preservation of plants to maintain the balance of the ecosystem.

The people around the buffer village area maintain the forest as part of their lives. One of them there are several ways that are considered unreasonable such as, should not take wood in the forest because it will cause anger of the delicate creatures forest protectors, if entering the forest should not be noisy if you do not want to be affected by disaster, abstinence from taking leaves or twigs if you do not want to be followed by supernatural creatures to get home. Such forest protection, is one form of protection that is very effective, so that the sustainability of the forest is maintained.

\section{PROHIBITION OF TAKING OR KILLING PEACOCKS}

Actually, the local community around Alas Purwo National Park has conservation methods. Local wisdom owned by the community, turns out to have conservation value in maintaining the sustainability of nature. Local wisdom in utilizing natural resources, until now is still done and believed to be hereditary. The purpose and purpose is in the form of symbols or signs in the form of prohibitions, such as abstinence from taking or killing peacocks. The prohibition of taking or killing peacocks, according to the public, is because peacocks are the favorite animals of the delicate creatures of Alas Purwo National Park. Peacocks are protected animals and unique because they have a golden color, the length can reach $300 \mathrm{~cm}$, with a long tail cover, and there is an upright crest above the head. There is a striking difference for female peacocks because they are smaller in size, the color of the fur is less shiny, without the decoration of the tail cover feathers. Peacocks have a high economic value and can be used as a nurturing animal for the benefit of ecotourism.

Until now it is still obeyed by the community around the national park area, because of its conservation values as the preservation of biodiversity. Peacocks are one component of the ecosystem, so that with the preservation of the animal the quality and quality of the ecosystem can indirectly be maintained. Birds have a role in various aspects of life, both ecological and socioeconomic. The increasing hunting of the existence of these animals because of their high economic value, becomes a strong reason to conduct further surveillance. One of them is conservation, an alternative to provide protection to animals. One of the programs conducted by Alas Purwo National Park Hall involves the surrounding community, namely breeding peacocks. The purpose of such activities is not only to protect but rather to increase the productivity of birds whose existence is beginning to be threatened. Bird breeding is certainly to increase the population to avoid extinction. Bird conservation activities should not only be carried out by government agencies by involving all components of society. There needs to be intensive coordination between formal and non-formal institutions, so that there is a more targeted synchronization in carrying out various conservation activities against birds.

\section{ABSTINENCE IN THE PAYANG SYSTEM}

Payang system includes fishing equipment or shrimp that has long been known by Indonesian fishermen. Payang is one of the traditional fishing tools that are still found in the field even though the number is getting smaller. Payang is a fishing tool that has long been used by Indonesian fishermen until now. Payang can be categorized as a tool that has high productivity and can be 
classified as a traditional fishing tool (40). Payang is a bag trawler used to catch hordes of surface fish (41). Payang is usually used to catch a type of surface fish (pelagic fish), where basically the construction of this fishing tool has parts consisting of nets (pockets, bodies and wings), buoys, ballast, ropes.

Nets are the main component of payang and most of the material of the payang construction consists of nets. In general, the construction consists of three parts (wings, body and pockets). Each part has different sizes and dimensions from one payang to another.

The bag section on the payang is a place to accommodate the catched fish. Usually the net on the bag is made of polyamide material.

The body of the net is part of the net, usually located in the middle of the net between the wings and the pouch. The size of the body length of the net varies between $16-18 \mathrm{~m}$. The length of the net depends on the size of the net eye used and the number of net points.

The wing is the longest section between $60-70 \mathrm{~m}$ of all payang sections consisting of both right wing and left wing. The length of the wings is intended to limit or cover the widest area of water so that it can quickly intercept hordes of pelagic fish that have a high swimming speed, in order to herd fish into the bag.

Buoys serve to help the opening of the mouth of the net, as well as to maintain the shape of the net as desired. All buoys are not permanently attached to the net, only installed at the time of operation of the net, after which it is removed again. This is done in order to facilitate the handling of nets so that the volume is not too large.

Ballast serves so that the bottom of the mouth of the net is submerged perfectly so that it forms the opening of the mouth of the net in order to gape to the maximum. Ballast serves so that the bottom of the net is well submerged so as to form a maximum net mouth opening (42). All weights except the bottom caka are not permanently installed. Ballast installation is carried out during the operation of the net, then after completion of the ballast hauling is removed.

Rigging is very supportive in the construction of payang, consisting of rope ris serves to strengthen the net and at the same time a place to tie the net. In payang usually consists of upper ris rope and lower ris rope is used on the wings and mouth nets. The rope is not tied to the net, but is only inserted into the eye of the net that is the outermost of the wings or the outer edge of the wing. This condition causes the opening of the eyes of the net to become irregular, at the time of withdrawal of the net, the eyes of the net tend to be closed, allowing small fish not to escape through the eyes of the net.

To support the operation of fishing using payang, there are several things that need to be considered, including the inspection of the engine on the boat, the provision of Fuel Oil (BBM), as well as the positioning of fishing equipment. Payang is usually operated in the surface area, because the target catches the fish that are clustered. The operation of payang in the water is at a depth of $250-350 \mathrm{~m}$ with a net depth ranging from $20-30 \mathrm{~m}$ so as not to impact on damage to marine ecosystems. The process of lowering the net is usually marked when the fisherman is getting ready to lower the raft from the ship and separate the atraktor with a large buoy where the ship is moored. Where 1 Crew (ABK) will descend to the rumpon to be tied to a long rope held by an ABK who is on the ship to stall and pull the rumpon during the operation.

After determining the direction for the capture operation, the ship will move around the rumpon. The process of circling the rumpon is done counterclockwise, where the position of the fishing gear is on the stern on the left side of the ship. When the ship is surrounded by rumpons, the first thing to do is throw a ball buoy that has been tied to a rope on one part of the wing. Furthermore, the reduction of the diving rope is done, then after the diving rope comes down, then the decrease of the wing part of the net. Then the decrease of buoys and ballast on the wings, the decrease of buoys and ballast is done alternately, where the decrease of the buoy is first continued with ballast, then the ball-shaped buoy located at the mouth of the upper net and ballast. After the wing part is lowered, it is followed by a decrease in the body of the bag and the wing part on the other side as well as the decrease of the diving rope.

Furthermore, in the process of net withdrawal is done after the nets are wrapped around the rumpon and the two ropes of the submarine meet, after the diving rope is already on board the ship, it will be carried out the 
withdrawal of the diving rope. The process of net withdrawal should be carried out quickly, in the hope of closing the chances of the fish escaping. The time it takes for the net to be drawn until all parts of the net go up the ship in about 8-15 minutes, the engine remains turned on at low speed until the catch on the net is on board. Once the bag is on board and is safe from the risk of escape of the catch, then the strap at the end of the bag is opened and the catch is placed on a box. The process of setting and hauling is done in the rumpon area at a depth of about $30 \mathrm{~m}$, located very far from the bottom of the water, so it does not interfere with the bottom of the water. In terms of payang operation, it does not indicate conditions that can damage the environment or fish resources.

Catching using a net can be done both at night and during the day. For the night, especially on dark days or not in the light of the moon using tools in the form of petromaks lamps. While catching done during the day using rumpon aids or just by guessing in a place that is thought to be a lot of fish. Usually in April, May, June, fishermen often use fishing gear with light aids and catching is carried out at night. Meanwhile, if it has entered the month of September, October, the fishermen use rumpon aids and the catch is carried out in the morning to evening (43). Rumpon is very simple and still made in the traditional way. The cloth of this rumpon includes dried coconut leaves, twigs, used tires, slap ropes and big stones that function ballast. Rumpon is a shape of nearby awareness that gives schooling on environmental conservation. It will actually have a wonderful effect at the environment, particularly with rumpon then as a domestic for fish as a refuge from predators, except that there may be a meals chain as a shape of herbal stability will arise across the rumpon. Of course, as a manifestation of the fishermen's community's difficulty for the environment, with the implementation of nearby awareness rumpon, it's far predicted that the destiny may be advanced with higher technology, withinside the shape of synthetic coral reef development.

Fishermen in Plengkung Beach know three fishing seasons, namely paceklik, medium and peak seasons. In the season the catch is very low, the time of the season is medium catch, while the peak season time of the catch is high. The system of fishing using the payang method, carried out on five days before the full moon until five days after the full moon because at that time there was a tide that resulted in fish and shrimp carried away by the current until it fell into the estuary. This system can only be implemented around a full moon, while on other days it cannot be done. The implementation of the payang system, there are some restrictions in the form of not being allowed to do other activities such as menjala. Based on trust, if it violates abstinence then the results obtained will be little. Fellow fish-seekers who use the payang system will advise their friends if they violate the restrictions. Conservation values contained in the payang system, utilization of natural resources by using simple and environmentally friendly equipment is always maintained ecosystem. There are some restrictions during payang by using other tools to take natural resources, there is a moral education that payang actors are invited to be wise in taking natural resources as necessary is not excessive.

\section{CONCLUSION}

Alas Purwo National Park has the potential to be a buffer of life because in its management it still applies local wisdom. The community around Alas Purwo National Park area has local wisdom in the form of a number of traditions, rules or restrictions that are still valid for generations which are then maintained and obeyed until now. The life of the people around the buffer village is very closely related to conservation efforts. This can be seen from the form of local wisdom, such as:

a. Prohibition of taking or killing peacocks. The abstinence is according to the belief of the community that peacocks are the favorite animals of the delicate creatures of Alas Purwo National Park. Currently still obeyed by the community around the national park area. In fact, with these restrictions they have implemented conservation values that exist in the community, indirectly an effort to preserve biodiversity. Peacocks are one component of the ecosystem, so that with the preservation of the animal the quality and quality of the ecosystem can indirectly be maintained intact.

b. Payang system including fishing equipment or shrimp that has long been 
widely known to Indonesian fishermen. This fishing gear is still traditional and has high productivity. Based on the belief if it violates abstinence, then the results obtained in the payday will be little. Conservation value contained in the payang system, in the form of utilization of natural resources by using simple and environmentally friendly equipment can minimize damaging marine ecosystems.

\section{ACKNOWLEDGEMENT}

Thank you to all parties involved in this research so that it is carried out properly. Special thanks to lpdp scholarship for research financing. Alas Purwo National Park Hall and the community around the buffer village.

\section{CONFLICT OF INTEREST}

There is no conflict of interest in this present research paper. This research work is not a part of any other studies and it is our original work.

\section{REFERENCES}

1. Warsito. Penyebaran dan Populasi Burung Paruh Bengkok Pada Beberapa Tipe Habitat di Papua. Jurnal Penelitian Hutan dan Konservasi Alam. 2010; 7(1): 93102.

2. Mangi H. Asosiasi Burung Julang Sulawesi (Rhyticeros cassidix) dengan Pohon Eboni (Diospyros celebica Bakh) di Cagar Alam Pangi Binangga Desa Pangi Kabupaten Parigi Moutong. Jurnal Warta Rimba. 2013; 1(1): 1-8.

3. Istiawati NF. Pendidikan Karakter Berbasis NilaiNilai Kearifan Lokal Adat Ammatoa Dalam Menumbuhkan Karakter Konservasi. Cendekia: Journal of Education and Teaching. 2016; 10(1):1.

4. Astirin. Permasalahan Pengelolaan Keanekaragaman Hayati di Indonesia. Jurnal Biodiversitas. 2000; 1(1): 3640.

5. Direktorat Jenderal Konservasi Sumberdaya Alam dan Ekosistem (KSDAE). Statistik Direktorat Jenderal KSDAE. Jakarta: KLHK. 2016.

6. Direktorat Jenderal Perlindungan Hutan dan Konservasi Alam (Ditjen PHKA). Statistik. Jakarta: Ditjend PHKA. 2014.

7. Magdalena. Peran Hukum Adat dalam Pengelolaan dan Perlindungan Hutan di Desa Sesaot, Nusa Tenggara Barat dan Desa Setulang, Kalimantan Timur. Jurnal Sosial Ekonomi. (online). 2013; 10(2): 110-121.

8. Soemarwoto Otto. Ekologi, Lingkungan Hidup dan Pembangunan. Jakarta: Djambatan. 2014.

9. Gauthama MP, Kuusrestuwardhani Akadri. Budaya Jawa dan Masyarakat Modern. Jakarta: BPPT Press. 2013.

10. Betrand J, Phillips A. Indegenous and traditional peoples and protected areas: principles, guidelines and case study. Cambbridge (UK): IUCN, Cambridge and WWF International. 2010.

11. Yuliati, Yayuk. Perubahan Ekologis Dalam Strategi Adaptasi Masyarakat di Pegunungan Tengger (Suatu Kajian Gender dan Lingkungan). Malang: UB Press. 2011. 12. Liliweri A. Pengantar Studi Kebudayaan. Bandung: Nusamedia. 2014.

13. Van Assendelf HB. Waterholes, Mammals and Human Impact in Alas Purwo Baluran National Park East Java Indonesia, An Inventory along the coast in 1991. FONC project, Fakultas Kehutanan Universitas Gajah Mada, Yogyakarta. 1991.

14. Pramusanti. Interaksi Masyarakat Sekitar dengan Taman Nasional Alas Purwo (Studi Kasus di Desa Kendalrejo Kecamatan Tegaldimo Kabupaten Banyuwangi Provinsi Jawa Timur) [Skripsi]. Bogor (ID): Institut Pertanian Bogor. 2001.

15. Febriyanti Dwiyandhi. Studi Nilai Manfaat Hutan Mangrove Resort Bedul bagi Masyarakat Sekitar Kawasan Taman Nasional Alas Purwo, Banyuwangi. Skripsi. Bogor (ID): Institut Pertanian Bogor. 2007.

16. Satyasar, Ika. Evaluasi Pengembangan Ekowisata Mangrove: Studi Kasus di Bedul, Resort Grajagan, Taman Nasional Alas Purwo, Jawa Timur. Skripsi. Bogor (ID): Institut Pertanian Bogor. 2010.

17. Azmi Rizka Syabana. Konservasi Spesies Kunci Budaya Masyarakat Desa Kalipahit di Sekitar Taman Nasional Alas Purwo, Jawa Timur. Skripsi. Bogor (ID): Institut Pertanian Bogor. 2015.

18. Fiddarain Arrajih. Rancangan Solusi Konflik Lahan di Taman Nasional Alas Purwo. Skripsi. Bogor (ID): Institut Pertanian Bogor. 2016.

19. Iswandono Elisa. Integrasi Kearifan Lokal Masyarakat Suku Manggarai dalam Konservasi Tumbuhan dan Ekosistem Pegunungan Ruteng Nusa Tenggara Timur (Disertasi). Bogor (ID): Institut Pertanian Bogor. 2016.

20. Kosmaryandi N. Pengembangan Zonasi Taman Nasional: Sintesis Kepentingan Konservasi Keanekaragaman hayati dan Kehidupan Masyarakat Adat [Disertasi]. Bogor (ID): Institut Pertanian Bogor. 2012.

21. Mendez-Lopez. Local participation in biodiversity conservation initiatives: a comparative analysis of different models in South East Mexico. Journal of Environmental Management. 2014; 125(1): 321-329.

22. Thaman. A comparison of rural comunity perceptions and involvement in conservations between the Fiji Island and Southwestern Portugal. Journal Ocean \& Coastal Management. 2016; 133 (2016): 43-52.

23. Aguilar-Stoen Mariel. Global forest conservations initiativies as spaces for participation in Colombia and Costa Rica. Journal Geoforum. 2015; 61 (2015) 36-44.

24. Ihsannudin. Fisherman's Behavior of Multi Ethnic Community In Adapting Climate Change In Small Island. International Journal of Andalas. 2015b; 2(2): 1-14.

25. Ihsannudin. The Role of Social Capital on Salt Smallholder Society of Madura Indonesia in Land Certification Ownership. Scientific Journal of PPI-UK. 2015a; 2(4): 144-151.

26. Liberati. Beyond Protection: Expanding Concervation Opportunity to Redefine Conservation Planning in the 21st Century. Journal of Environmental Management. 2016.

http://dx.doi.org/10.1016/j.jenvman.2016.08.041. 
27. Freitas DMD, Tagliani PRA. The Use of GIS for The Integration of Traditional and Scientific Knowledge in a Supporting Artisanal Fisheries Management in Southern Brazil. Journal of Enviromental Management. 2009; 90(6): 2071-2078.

28. Bohensky EL, Maru Y. Indigenous Knowledge, Science, and Resilience: What Have We Learned from a Decade of International Literature on Integration? Ecology and Society. 2011; 16(4): 1-7.

29. Fraser DJ, Coon T, Prince MR, Dion R, Bernatchez L. Integrating Traditional and Evolutionary Knowledge in Biodiversity Conservation: a Population Level Case Study. Journal Ecology and Society. 2006; 11(2): 1-7.

30. Naidoo R, Hill K. Emergence of Indigenous Vegetation Classifications Through Integration of Traditional Ecological Knowledge and Remote Sensing Analyses. Journal Enviromental Management. 2006; 38(3): 377386.

31. Denzin, NK, YS Lincoln (eds). Handbook of Qualitatif Research (Second Edition), Thousand Oaks, London, New Delhi: Sage Publication. 2000.

32. Rahmat Jalaluddin. Metode Penelitian Komunikasi. Bandung: Remaja Rosdakarya. 2010.

33. Sarwono J. Metode Penelitian Kuantitatif dan Kualitatif. Yogyakarta: Graha Ilmu. 2006.

34. Iskandar. Metodologi Penelitian Kualitatif. Jakarta: Gaung Persada. 2009.

35. Sukardi. Metodologi Penelitian Pendidikan Kompetensi dan Praktiknya. Jakarta: Bumi Aksara. 2008.
36. Neuman William Lawrence. Social Research Methods: Qualitative and quantitative Approaches. Pearson Education. 2003.

37. Alikodra HS. Konservasi sumberdaya alam dan lingkungan. Pendekatan ecosophy bagi penyelamatan bumi. Yogyakarta: Gadjah Mada University Press. 2012.

38. Poerwanto Hari. Kebudayaan dan Lingkungan: Dalam Persepektif Antropologi. Yogyakarta: Pustaka Pelajar. 2000.

39. Agusyanto. Jaringan Sosial. Jakarta: UI Press. 2012.

40. Palo M., Assir A. Analisis Aspek Teknis Jaring Payang

Di Perairan Mamuju, Sulawesi Barat Analyses on Technical Aspects of Scottish Seine Net in. 2019; 6(12): 214-229.

41. Brandt AV. Classification of Fisher Gear, Modern Fishir Gear of The World. Fishing News. Ltd London. 1995.

42. Boesono WAH. Analisis Efisiensi Teknis Genuine Payang Dan Modifikasi Payang Dengan Windows Samping Terhadap Hasil Tangkapan Di Perairan Kabupaten Kendal. Journal of Fisheries Resources Utilization Management and Technology. 2014; 3: 4653.

43. Amry RA, Renta PP, Nofridiansyah E. Analisa Kelayakan Usaha Penangkapan Ikan Menggunakan Alat Tangkap Payang (Seine Net) Menggunakan Alat Bantu Rumpon Di Pantai Malabero Kota Bengkulu. Jurnal Enggano. 2017; 2(2): 129-142. 